\title{
Iron Mineralizing Bacterioferritin A from Mycobacterium tuberculosis exhibits Unique Catalase-Dps like Dual Activities
}

\author{
Abhinav Mohanty ${ }^{1}$, Biswamaitree Subhadarshanee ${ }^{1,2}$, Pallavi Barman ${ }^{1 \#}$, Chinmayee \\ Mahapatra $^{1 \#}$, B. Aishwarya ${ }^{1 \#}$, Rabindra K. Behera ${ }^{1} *$ \\ ${ }^{1}$ Department of Chemistry, National Institute of Technology, Rourkela - 769008, Odisha, \\ India. ${ }^{2}$ School of Biotechnology, KIIT Deemed to be University, Bhubaneswar-751024, \\ Odisha, India. \\ \# These authors contributed equally to this work.
}

*To whom correspondence should be addressed: Rabindra K. Behera, Tel: +91-661-2462980; Fax: +91-661-2462651; E-mail: beherarabi@ nitrkl.ac.in 
Table S1: Oligonucleotide primer designed for site directed mutagenesis to modify WT BfrA surface.

\begin{tabular}{|c|l|}
\hline WT BfrA Variant & Oligonucleotide Primers (5' to 3') \\
\hline M52L_For & CGTGCCGCAATTCGTCGAACGACTCCG \\
\hline M52L_Rev & CGGAGTCGTTCGACGAATTGCGGCACG \\
\hline
\end{tabular}

Positions where changes in DNA sequences were made are shown by bold font and underlined.

Table S2: Kinetic parameters for the formation of DFP like intermediates and $\left[\mathrm{Fe}^{3+} \mathrm{O}\right]_{\mathrm{x}}$ species in recombinant Mtb BfrA protein. The Hill coefficient (n, cooperativity), was obtained from Hill plots of initial rate $\left(\mathrm{v}_{\mathrm{i}}\right)$ vs. $\mathrm{Fe}^{2+} /$ cage using Hill equation, $\mathrm{v}_{\mathrm{i}}=$ $\mathrm{V}_{\max } *\left[\mathrm{Fe}^{2+}\right]^{\mathrm{n}} /\left(\left(\mathrm{K}_{\mathrm{m}}\right)^{\mathrm{n}}+\left[\mathrm{Fe}^{2+}\right]^{\mathrm{n}}\right)$; Hill coefficient values $(\mathrm{n})$ are significantly $>1.0$. The data are average of two independent experiments (see Fig.2.B and Fig.2.C), using two different protein preparations with the error as SD. Final concentrations of Mtb BfrA protein cages were $2.08 \mu \mathrm{M}$ in $100 \mathrm{mM}$ MOPS (pH 7.0).

\begin{tabular}{|c|c|c|c|c|c|c|}
\hline & Samples & $\begin{array}{l}\text { S.A. }{ }^{\text {a }} \text { X } 10 \\
\left(s^{-1} \text { per } \mathrm{mg}\right. \\
\text { of protein })\end{array}$ & $\begin{array}{c}\mathbf{v}_{\max } \\
\left(\Delta \mathbf{A} / \mathbf{t i m e}^{-1}\right) \\
\left(\mathbf{s}^{-1}\right)\end{array}$ & $\begin{array}{c}\mathbf{K}_{\mathrm{m}} \\
(\boldsymbol{\mu M})\end{array}$ & $\begin{array}{c}\mathbf{k}_{\mathbf{c a t}}{ }^{b} \\
\left(\mu \mathbf{M}^{-1} \mathbf{s}^{-1}\right)\end{array}$ & $\begin{array}{c}\text { Hill } \\
\text { coefficient } \\
\text { 'n' }\end{array}$ \\
\hline \multirow[t]{2}{*}{$\mathrm{A}_{350 \mathrm{~nm}}$} & $\mathrm{BfrA}+\mathrm{Fe}^{2+}+\mathrm{O}_{2}$ & $56.1 \pm 2.6$ & $5.19 \pm 0.24$ & $222.1 \pm 16.1$ & $2.49 \pm 0.12$ & $2.1 \pm 0.3$ \\
\hline & $\mathrm{Bfr} \mathrm{A}+\mathrm{Fe}^{2+}+\mathrm{O}_{2}+\mathrm{H}_{2} \mathrm{O}_{2}$ & $61.1 \pm 2.1$ & $5.65 \pm 0.19$ & $205.6 \pm 10.2$ & $2.72 \pm 0.09$ & $2.6 \pm 0.3$ \\
\hline \multirow[t]{2}{*}{$\mathrm{A}_{650 \mathrm{~nm}}$} & $\mathrm{Bfr} \mathrm{A}+\mathrm{Fe}^{2+}+\mathrm{O}_{2}$ & $11.0 \pm 0.4$ & $1.02 \pm 0.04$ & $189.7 \pm 9.4$ & $0.49 \pm 0.02$ & $3.5 \pm 0.6$ \\
\hline & $\mathrm{BfrA}+\mathrm{Fe}^{2+}+\mathrm{O}_{2}+\mathrm{H}_{2} \mathrm{O}_{2}$ & $8.9 \pm 0.4$ & $0.83 \pm 0.04$ & $134.8 \pm 10.1$ & $0.39 \pm 0.02$ & $3.0 \pm 0.6$ \\
\hline
\end{tabular}

${ }^{a}$ Specific activity (S.A.) for ferroxidase reaction: $\Delta \mathrm{A} / \Delta \mathrm{t}\left(\mathrm{s}^{-1}\right) / \mathrm{mg}$ of protein.

${ }^{\mathrm{b}}$ Computed from the formula for turnover number: $\mathrm{k}_{\mathrm{cat}}=\mathrm{v}_{\mathrm{max}} /\left[\mathrm{E}_{\mathrm{T}}\right]$ where $\left[\mathrm{E}_{\mathrm{T}}\right]$ is total enzyme (BfrA) concentration ( $2.08 \mu \mathrm{M}$ final cage concentration). 
Table S3: Kinetic parameters obtained from the catalase activity of recombinant $M t b$ BfrA protein. The kinetics of $\mathrm{O}_{2}$ evolution (using Clark type microelectrode) were monitored in two sets of experiments (using different protein preparations): (1) by varying the $\mathrm{H}_{2} \mathrm{O}_{2}$ concentration (0.25-3.0 $\mathrm{mM})$ at fixed BfrA concentration (1.0 $\mu \mathrm{M}$ cage) and (2) by varying the $\mathrm{H}_{2} \mathrm{O}_{2}$ concentration $(5-100 \mathrm{mM})$ at fixed BfrA concentration $(0.3 \mu \mathrm{M}$ cage). The apparent values of catalytic terms are calculated from the double reciprocal Lineweaver-Burk (LB) plot for the initial rate of $\mathrm{O}_{2}$ evolution by $M t b$ BfrA as a function of $\mathrm{H}_{2} \mathrm{O}_{2}$ concentration. All the reaction samples were prepared in $100 \mathrm{mM}$ MOPS buffer $(\mathrm{pH} 7.0)$.

\begin{tabular}{|cccccc|}
\hline Sl. No. & $\begin{array}{c}{\left[\mathbf{H}_{\mathbf{2}} \mathbf{O}_{\mathbf{2}}\right]} \\
(\mathbf{m M})\end{array}$ & $\mathbf{V}_{\mathbf{m a x}} \mathbf{a}$ & $\begin{array}{c}\mathbf{K}_{\mathbf{m}} \\
(\mathbf{m M})\end{array}$ & $\begin{array}{c}\mathbf{k}_{\mathbf{c a t}} / \mathbf{c a g e}^{\mathbf{b}} \\
\left(\mathbf{s}^{\mathbf{- 1}}\right)\end{array}$ & $\begin{array}{c}\mathbf{k}_{\mathbf{c a t}} / \mathbf{K}_{\mathbf{m}} \\
\left(\mathbf{m M}^{-\mathbf{1}} \mathbf{s}^{-\mathbf{1}}\right)\end{array}$ \\
\hline 1 & $0.25-3.0$ & $4851.9 \pm 128.2$ & $32.8 \pm 2.2$ & $35.9 \pm 9.5$ & 1.09 \\
2 & $5-100$ & $2821.1 \pm 227.3$ & $71.1 \pm 4.0$ & $20.9 \pm 1.7$ & 0.29 \\
\hline
\end{tabular}

${ }^{\mathrm{a}} \mathrm{v}_{\max }$ (apparent), $\mu \mathrm{M} \mathrm{H} \mathrm{H}_{2} \mathrm{O}_{2}$ per min per mg of protein.

${ }^{\mathrm{b}}$ Computed from the formula for turnover number: $\mathrm{k}_{\mathrm{cat}}$ (apparent) $=\mathrm{v}_{\max } /\left[\mathrm{E}_{\mathrm{T}}\right]$ where $\left[\mathrm{E}_{\mathrm{T}}\right]$ is total enzyme (Mtb BfrA cage) concentration.

Table S4: UV- visible absorption spectral features are listed for various heme proteins in their ferric form.

\begin{tabular}{|c|c|c|c|c|}
\hline Heme-Protein & $\begin{array}{c}\text { Soret } \\
\text { band (nm) }\end{array}$ & $\begin{array}{c}\text { High spin } \\
\text { Fe(III) band } \\
(\mathrm{nm})\end{array}$ & $\begin{array}{c}\text { Bis-methionine } \\
\text { heme band } \\
\text { (nm) }\end{array}$ & Ref. \\
\hline WT $M t b$ BfrA & 410 & 623 & 735 & This work \\
\hline WT E.coli Bfr & 418 & - & 739 & 1 \\
\hline WT $P a$ Bfr & 417 & - & 740 & 2 \\
\hline Bovine liver Catalase & 404 & 623 & - & This work \\
\hline Horse heart Met-Mb & 409 & 628 & - & 3 \\
\hline Horse radish peroxidase (HRP) & 402 & 648 & - & 4 \\
\hline Cyt P450cam (camphor bound form) & 392 & 645 & - & 5 \\
\hline Yeast iso-1-Cytochrome c (M80A) & 406 & 626 & - & 6 \\
\hline Cytochrome c552 (M69A) & 398 & 625 & - & 7 \\
\hline
\end{tabular}




\section{References:}

1. Cheesman, M. R.; le Brun, N. E.; Kadir, F. H. A.; Thomson, A. J.; Moore, G. R.; Andrews, S. C.; Guest, J. R.; Harrison, P. M.; Smith, J. M. A.; Yewdall, S. J. Haem and nonhaem iron sites in Escherichia coli bacterioferritin: spectroscopic and model building studies. Biochemical Journal 1993, 292 (1), 47 DOI: 10.1042/bj2920047.

2. Rivera, M. Bacterioferritin: Structure Function and Protein-Protein Interactions. 30 ed.; World Scientific Publishing Co. Pte. Ltd. Singapore: 2013; p 135-178.

3. Bowen, W. J. The absorption spectra and extinction coefficients of myoglobin. J Biol Chem 1949, 179 (1), 235-45.

4. Adak, S.; Mazumdar, A.; Banerjee, R. K. Low catalytic turnover of horseradish peroxidase in thiocyanate oxidation. Evidence for concurrent inactivation by cyanide generated through one-electron oxidation of thiocyanate. J Biol Chem 1997, 272 (17), 1104956.

5. Behera, R. K.; Mazumdar, S. Roles of two surface residues near the access channel in the substrate recognition by cytochrome P450cam. Biophys Chem 2008, 135 (1-3), 1-6.

6. Lu, Y.; Casimiro, D. R.; Bren, K. L.; Richards, J. H.; Gray, H. B. Structurally engineered cytochromes with unusual ligand-binding properties: expression of Saccharomyces cerevisiae Met-80-->Ala iso-1-cytochrome c. Proc Natl Acad Sci U S A 1993, 90 (24), 11456-9.

7. Behera, R. K.; Nakajima, H.; Rajbongshi, J.; Watanabe, Y.; Mazumdar, S. Thermodynamic effects of the alteration of the axial ligand on the unfolding of thermostable cytochrome C. Biochemistry 2013, 52 (8), 1373-84. 


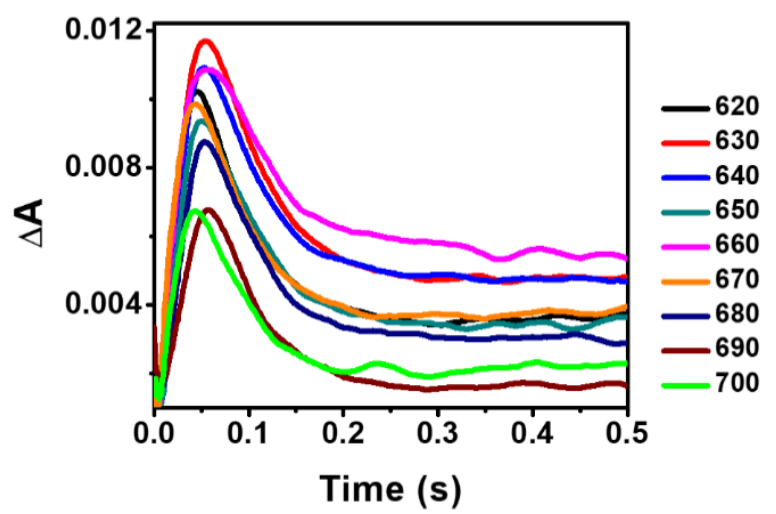

Figure S1: Detection of DFP like transient intermediate during ferroxidase activity of Mtb BfrA. Formation/decay of diferric peroxo (DFP) like catalytic intermediate during the ferroxidase activity of $M t b \mathrm{BfrA}$ (at $100 \mathrm{Fe} /$ cage) monitored at different wavelengths ranging from $620-700 \mathrm{~nm}$. BfrA protein $(4.16 \mu \mathrm{M}$ cage) solution in $100 \mathrm{mM}$ MOPS buffer ( $\mathrm{pH} 7.0)$ was mixed with an equal volume of freshly prepared $\mathrm{FeSO}_{4}$ solution, at room temperature in a rapid mixing stopped flow spectrophotometer.
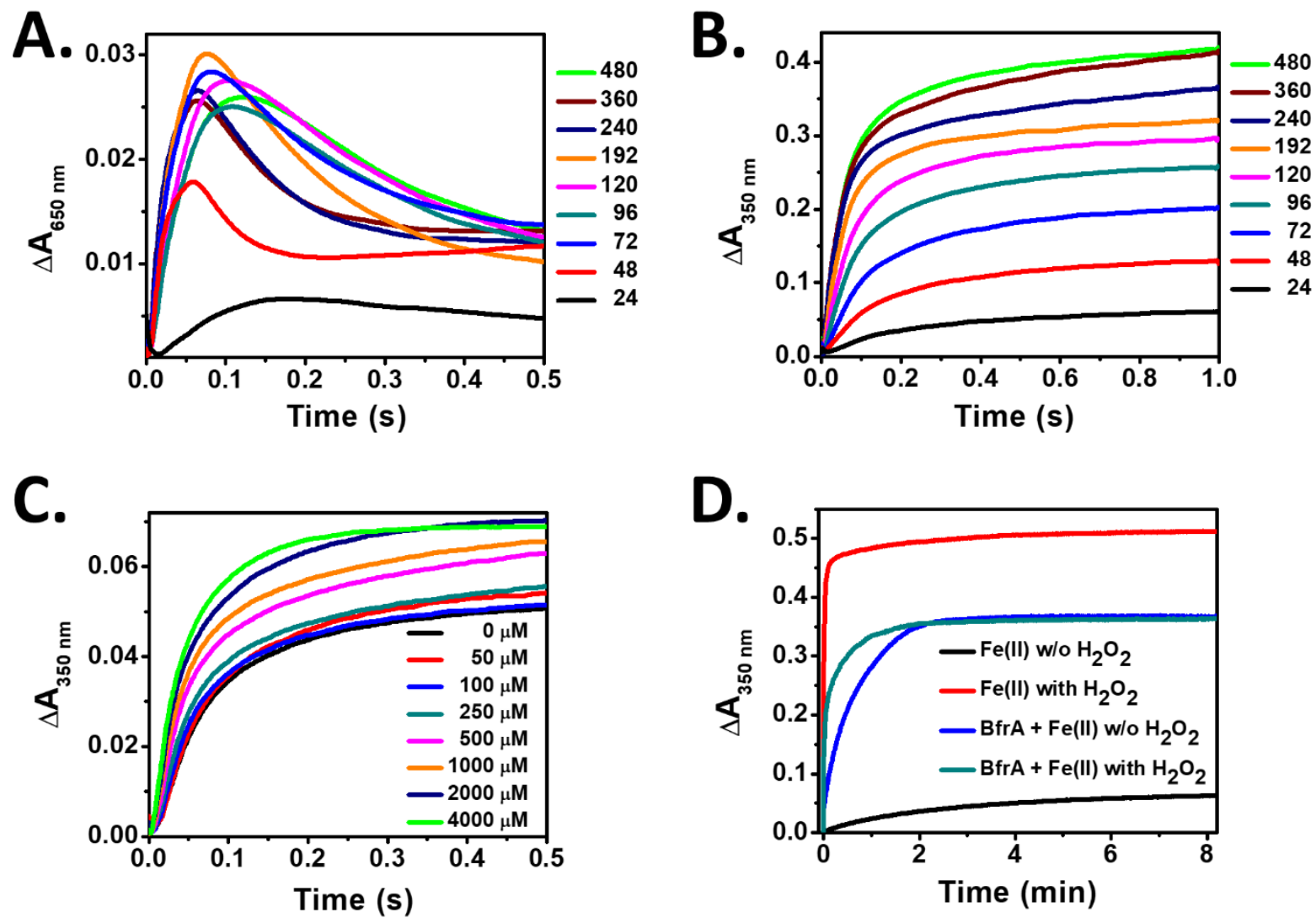

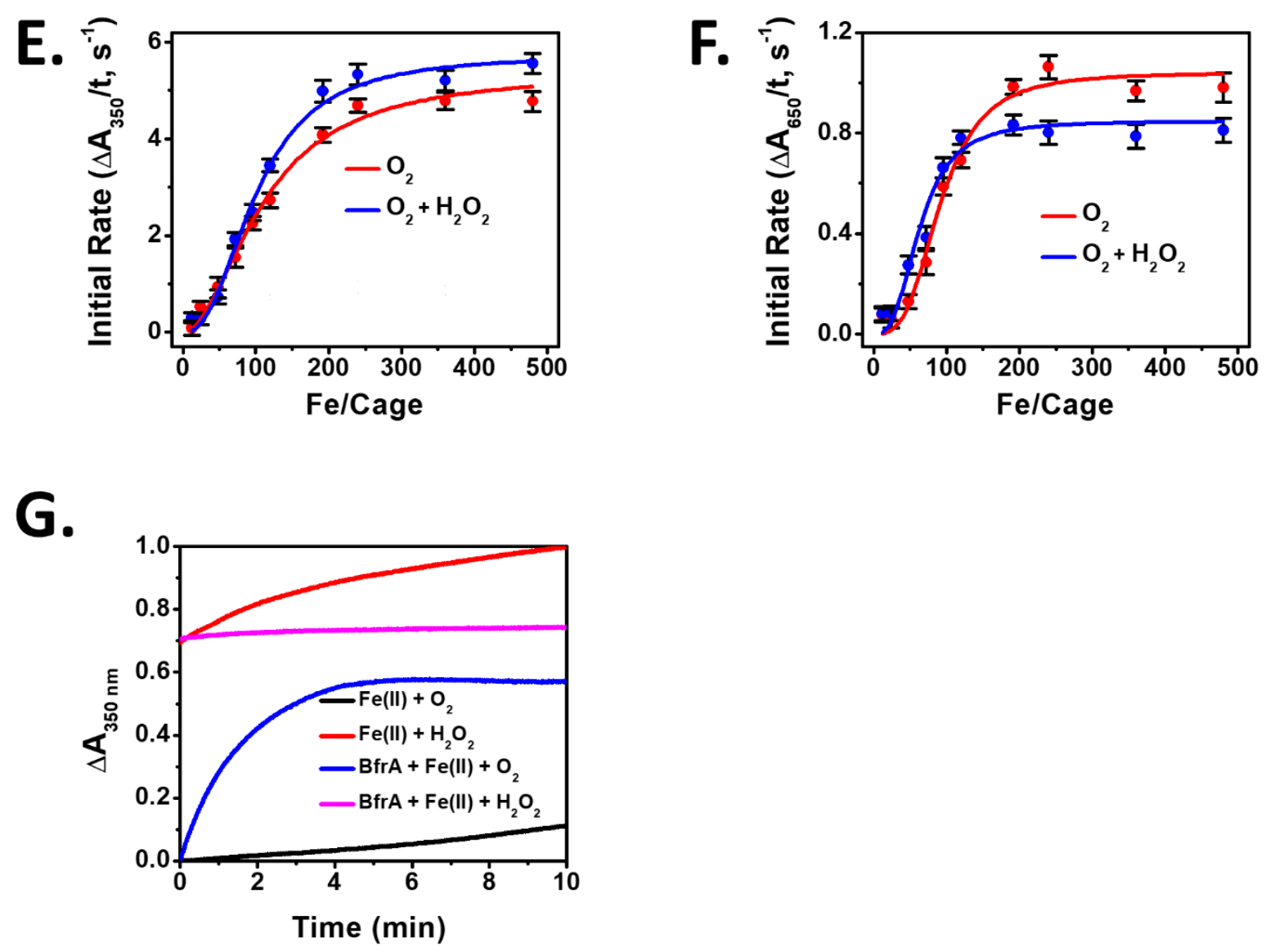

Figure S2: Comparison of kinetics of ferroxidase activity in the presence/absence of both $M t b$ BfrA and $\mathrm{H}_{2} \mathrm{O}_{2}$. Progress curves of: (A) formation/decay of diferric peroxo (DFP) like catalytic intermediate at $650 \mathrm{~nm}$ and $(\mathbf{B})\left[\mathrm{Fe}^{3+}-\mathrm{O}\right]_{\mathrm{x}}$ formation at $350 \mathrm{~nm}$ by $\mathrm{Mtb} \mathrm{BfrA}(2.08$ $\mu \mathrm{M}$ cage final concentration), with increasing Fe/cage (24 - 480) in the presence of $\mathrm{H}_{2} \mathrm{O}_{2}(250$ $\mu \mathrm{M})$. (C) Progress curve for $\left[\mathrm{Fe}^{3+}-\mathrm{O}\right]_{\mathrm{x}}$ formation by $\mathrm{Mtb}$ BfrA $(0.5 \mu \mathrm{M}$ cage final concentration) containing $100 \mathrm{Fe} /$ cage, with increasing $\mathrm{H}_{2} \mathrm{O}_{2}(0-4000 \mu \mathrm{M})$. (D) Kinetics of iron oxidation at $350 \mathrm{~nm}$ in the absence and presence of Mtb BfrA (1.0 $\mu \mathrm{M}$ cage) at 500 $\mathrm{Fe} /$ cage under aerobic condition $\left(\mathrm{O}_{2}+\mathrm{H}_{2} \mathrm{O}_{2}\right)$ monitored using stopped flow spectrometry. The initial rates of ferroxidase activity, in the absence and presence of $\mathrm{H}_{2} \mathrm{O}_{2}(250 \mu \mathrm{M})$, as a function of iron loading per $M t b$ BfrA cage were fitted to Hill equation for: $(\mathbf{E})\left[\mathrm{Fe}^{3+}-\mathrm{O}\right]_{\mathrm{x}}$ formation at $350 \mathrm{~nm}$ and (F) formation of DFP like intermediate at $650 \mathrm{~nm}$. (G) Time course of iron oxidation in the absence and presence of $\mathrm{Mtb} \mathrm{BfrA}(1.0 \mu \mathrm{M}$ cage $)$ at $500 \mathrm{Fe} /$ cage under the presence of either only $\mathrm{O}_{2}$ or only $\mathrm{H}_{2} \mathrm{O}_{2}$ (anaerobic condition), monitored using SHIMADZU UV-visible spectrophotometer. During anaerobic experiments, all the samples ( $M t b$ BfrA, $\mathrm{FeSO}_{4}$ and $\mathrm{H}_{2} \mathrm{O}_{2}$ ) were individually purged with $\mathrm{N}_{2}$ gas for 10 minutes prior to the start of experiment. The reaction samples were prepared in $100 \mathrm{mM}$ MOPS buffer ( $\mathrm{pH}$ 
7.0) and required amounts of $\mathrm{FeSO}_{4}$ and $\mathrm{H}_{2} \mathrm{O}_{2}(250 \mu \mathrm{M})$ were manually added. Control experiments for iron oxidation were also performed in the absence of $M t b$ BfrA protein.
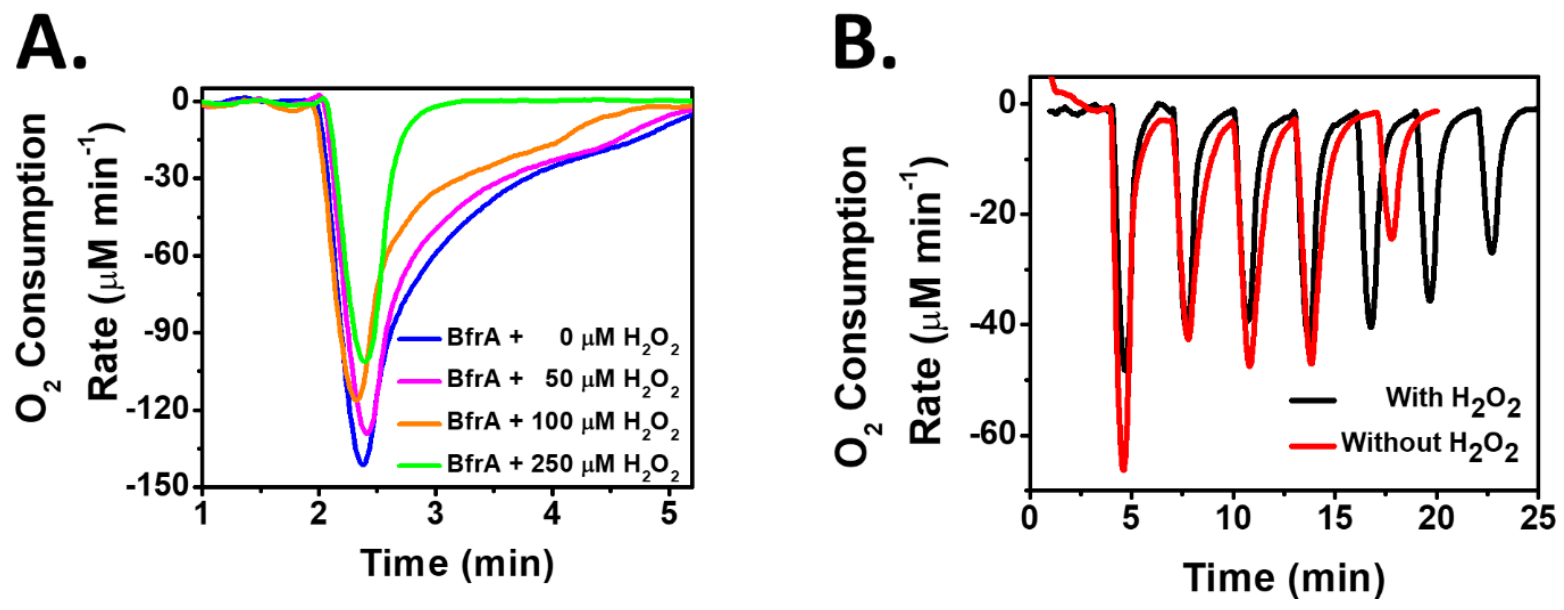

Figure S3: Comparison of $\mathrm{O}_{2}$ consumption rate during the $\mathrm{O}_{2} / \mathrm{H}_{2} \mathrm{O}_{2}$ based ferroxidase activity of Mtb BfrA. The rate of $\mathrm{O}_{2}$ consumption (in the presence and absence of $\mathrm{H}_{2} \mathrm{O}_{2}$ ) were compared by varying the concentration of (A) $\mathrm{H}_{2} \mathrm{O}_{2}(0-250 \mu \mathrm{M})$ keeping $\mathrm{FeSO}_{4}$ and Mtb BfrA cage concentration fixed at $500 \mu \mathrm{M}$ and $1.0 \mu \mathrm{M}$ respectively, (B) $\mathrm{H}_{2} \mathrm{O}_{2}(0 \mu \mathrm{M}$ during absence and $60 \mu \mathrm{M}$ during presence; for each addition) for $M t b$ BfrA (1.0 $\mu \mathrm{M}$ cage) by keeping $\mathrm{FeSO}_{4}$ concentration fixed at $120 \mu \mathrm{M}$ for each addition. The reaction samples were prepared in $100 \mathrm{mM}$ MOPS buffer ( $\mathrm{pH}$ 7.0) and required amounts of $\mathrm{FeSO}_{4}$ and $\mathrm{H}_{2} \mathrm{O}_{2}$ were added (with a time delay of about $10 \mathrm{~s}$ between them). 

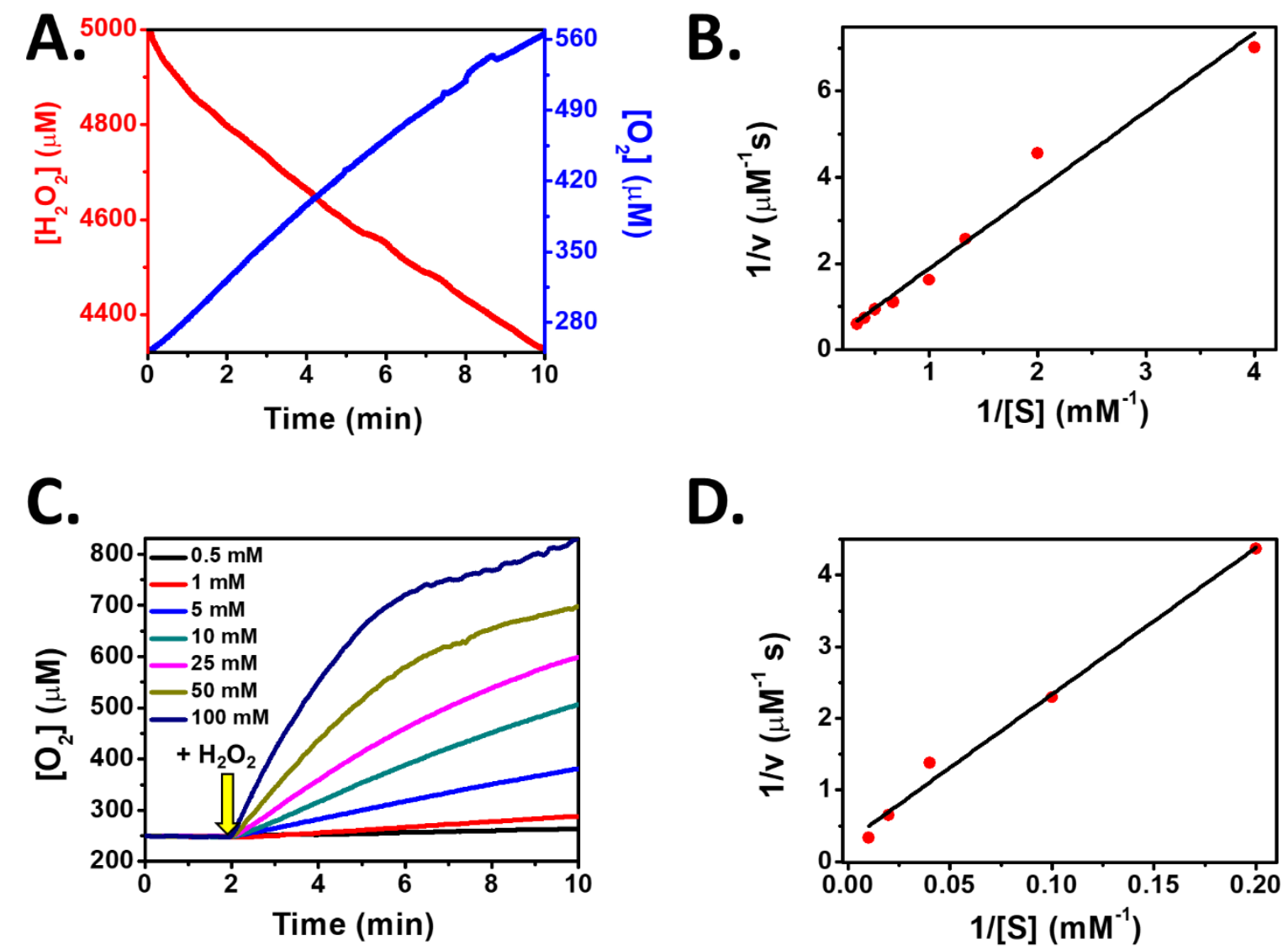

Figure S4: Investigating the catalase-like activity during the reaction of $\mathrm{H}_{2} \mathrm{O}_{2}$ with $M t b$ BfrA. (A) The kinetics of $\mathrm{O}_{2}$ evolution (using Clark type microelectrode) and $\mathrm{H}_{2} \mathrm{O}_{2}$ disproportionation (by monitoring the kinetics at $240 \mathrm{~nm}$ using UV-visible spectrophotometer) were investigated for $\mathrm{H}_{2} \mathrm{O}_{2}(5 \mathrm{mM})$ in the presence of $M t b$ BfrA $(0.3 \mu \mathrm{M}$ cage). (C) The time courses of $\mathrm{O}_{2}$ evolution were monitored by varying the $\mathrm{H}_{2} \mathrm{O}_{2}$ concentration $(0.5-100 \mathrm{mM})$ at fixed BfrA concentration $(0.3 \mu \mathrm{M}$ cage). Double reciprocal Lineweaver-Burk (LB) plot: (B) for the initial rate of $\mathrm{O}_{2}$ evolution by Mtb BfrA $(1.0 \mu \mathrm{M}$ cage) as a function of $\mathrm{H}_{2} \mathrm{O}_{2}$ concentration $(0-3 \mathrm{mM})$ and (D) for the initial rate of $\mathrm{O}_{2}$ evolution by $M t b$ BfrA $(0.3 \mu \mathrm{M}$ cage $)$ as a function of $\mathrm{H}_{2} \mathrm{O}_{2}$ concentration $(0.5-100 \mathrm{mM})$. All the reaction samples were prepared in $100 \mathrm{mM}$ MOPS buffer ( $\mathrm{pH}$ 7.0). Arrow (in yellow) indicates the time point of addition of $\mathrm{H}_{2} \mathrm{O}_{2}$ to $M t b$ BfrA solution. 

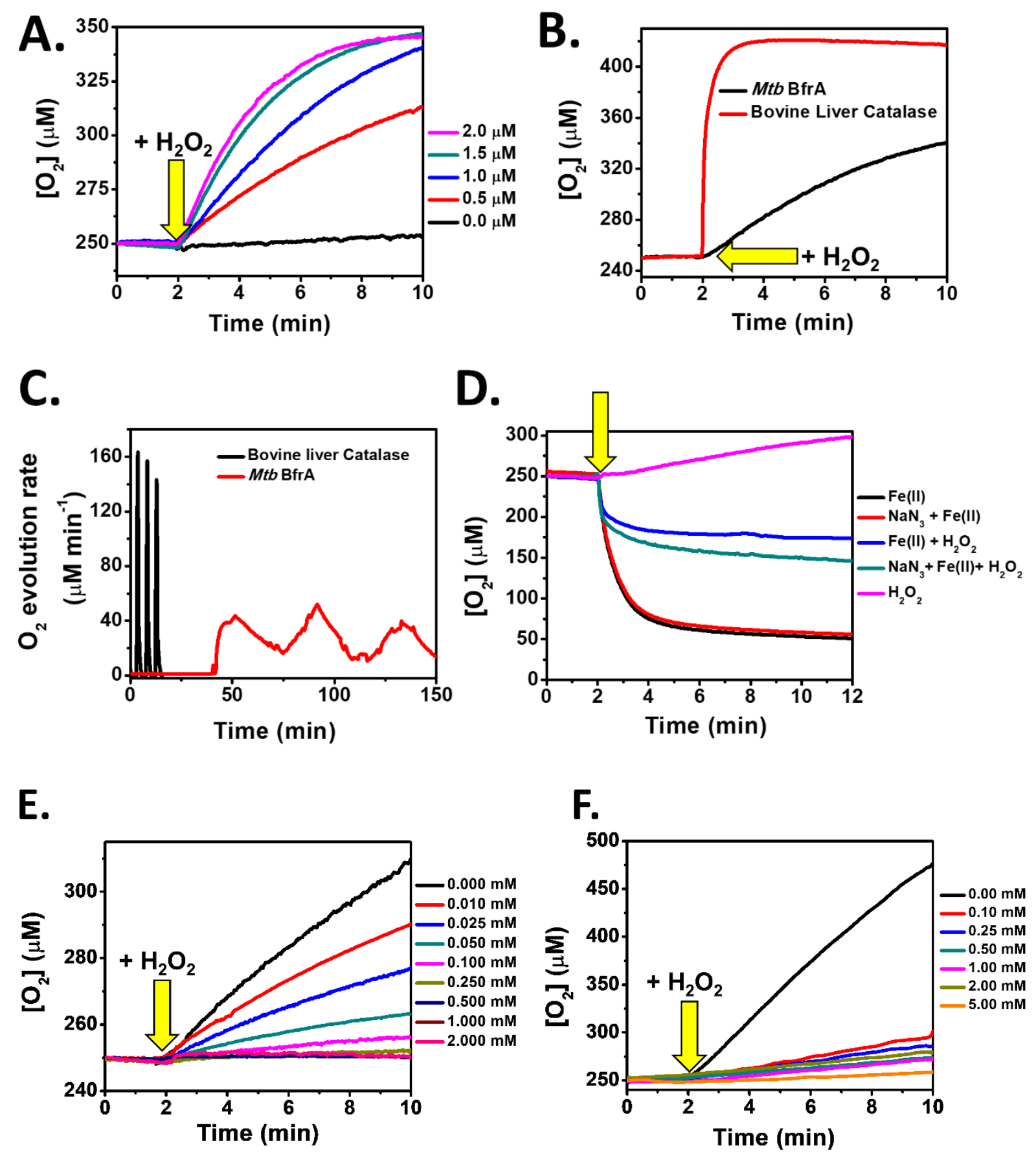

Figure S5: Monitoring the effect of catalase inhibitor on catalase-like activity of $M t b$ BfrA and its comparison with bovine liver catalase. (A) Kinetics of $\mathrm{O}_{2}$ evolution at fixed concentration of $\mathrm{H}_{2} \mathrm{O}_{2}(250 \mu \mathrm{M})$ with varying cage concentration of $M t b$ BfrA $(0-2 \mu \mathrm{M})$. Comparison of catalase activity of $M t b$ BfrA and bovine liver catalase (keeping heme concentration same): (B) kinetics of $\mathrm{O}_{2}$ evolution in the presence of $\mathrm{H}_{2} \mathrm{O}_{2}(250 \mu \mathrm{M})$ and $(\mathbf{C})$ rate of $\mathrm{O}_{2}$ evolution over 3 catalytic cycles of $\mathrm{H}_{2} \mathrm{O}_{2}(250 \mu \mathrm{M}$ each step) disproportionation. (D) Kinetics of $\mathrm{O}_{2}$ consumption during iron $(500 \mu \mathrm{M})$ oxidation both in the absence and presence of $\mathrm{H}_{2} \mathrm{O}_{2}(250 \mu \mathrm{M})$ and $\mathrm{NaN}_{3}(2 \mathrm{mM})$. The magenta colored curve represents the $\mathrm{O}_{2}$ 
evolution by $M t b$ BfrA in presence of only $\mathrm{H}_{2} \mathrm{O}_{2}(250 \mu \mathrm{M})$. Kinetics of $\mathrm{O}_{2}$ evolution by $M t b$ BfrA at fixed concentration of $\mathrm{H}_{2} \mathrm{O}_{2}(5 \mathrm{mM})$ with varying concentration of (E) $\mathrm{NaN}_{3}(0-2$ $\mathrm{mM}$ ) and (F) $\mathrm{NaCN}(0-5 \mathrm{mM})$. Inhibition of catalase-like activity of Mtb BfrA was monitored with two different protein preparations incubated with different concentrations of $\mathrm{CN}^{-} / \mathrm{N}_{3}{ }^{-}$for 5 min each (keeping the heme concentration same). All the reaction samples were prepared in $100 \mathrm{mM}$ MOPS buffer (pH 7.0). Arrows (in yellow) indicate the time point of addition of $\mathrm{H}_{2} \mathrm{O}_{2}$ and/or $\mathrm{FeSO}_{4}$ to $M t b$ BfrA solution.
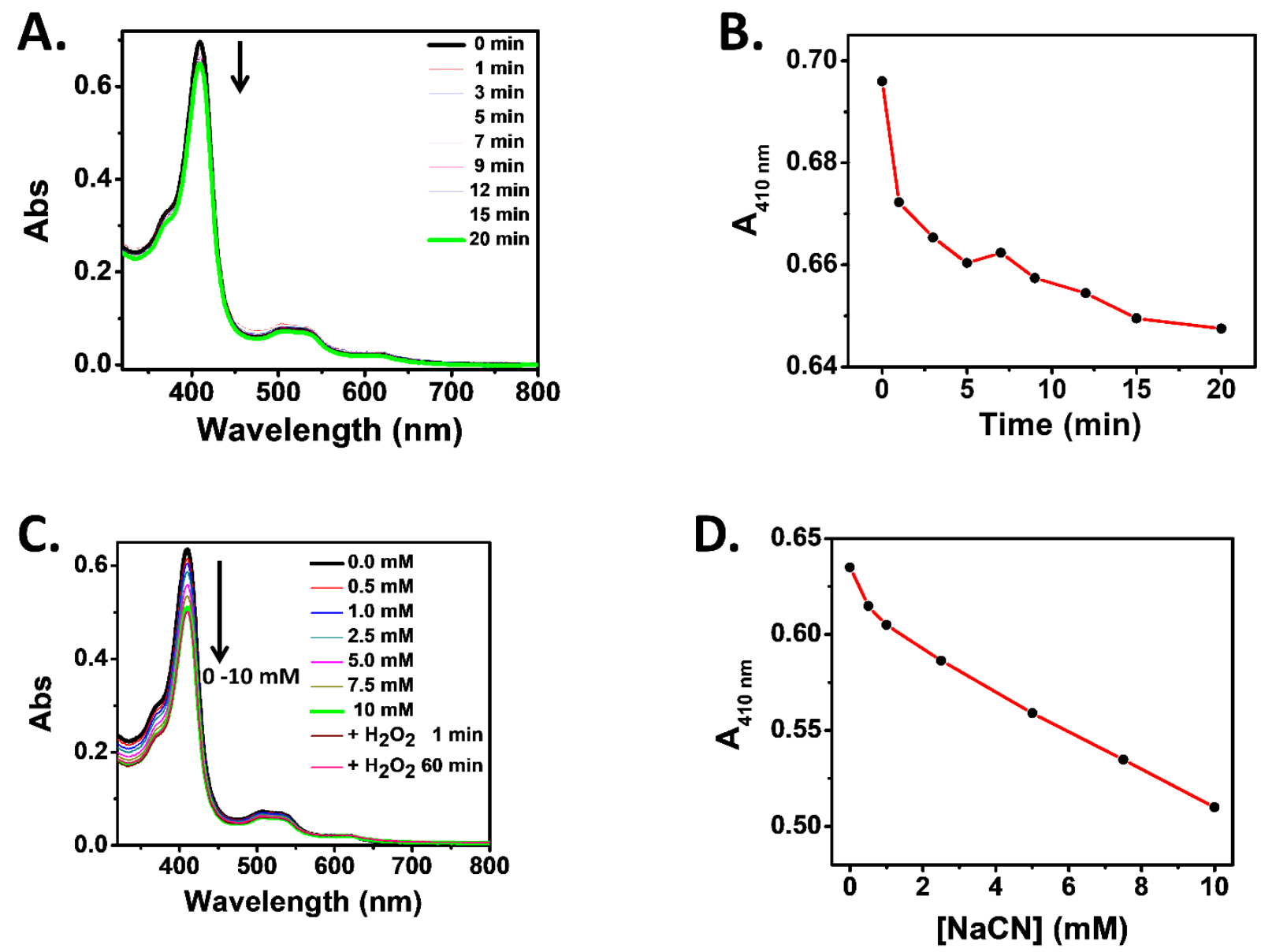

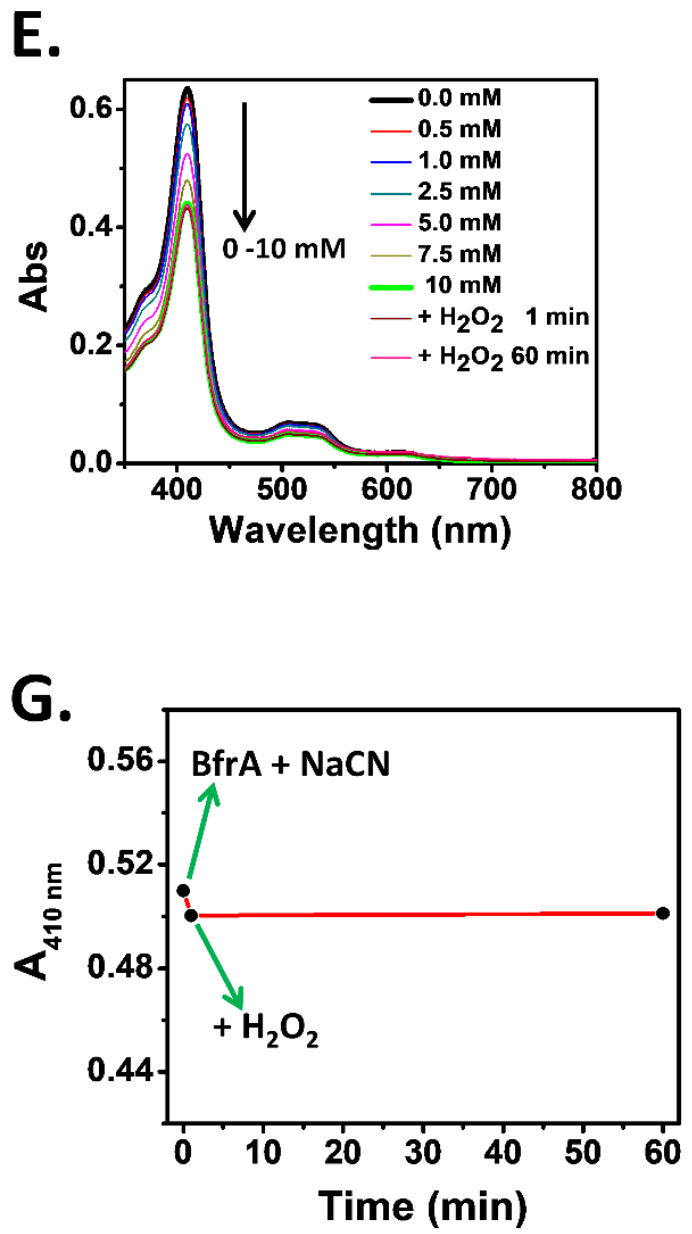

F.
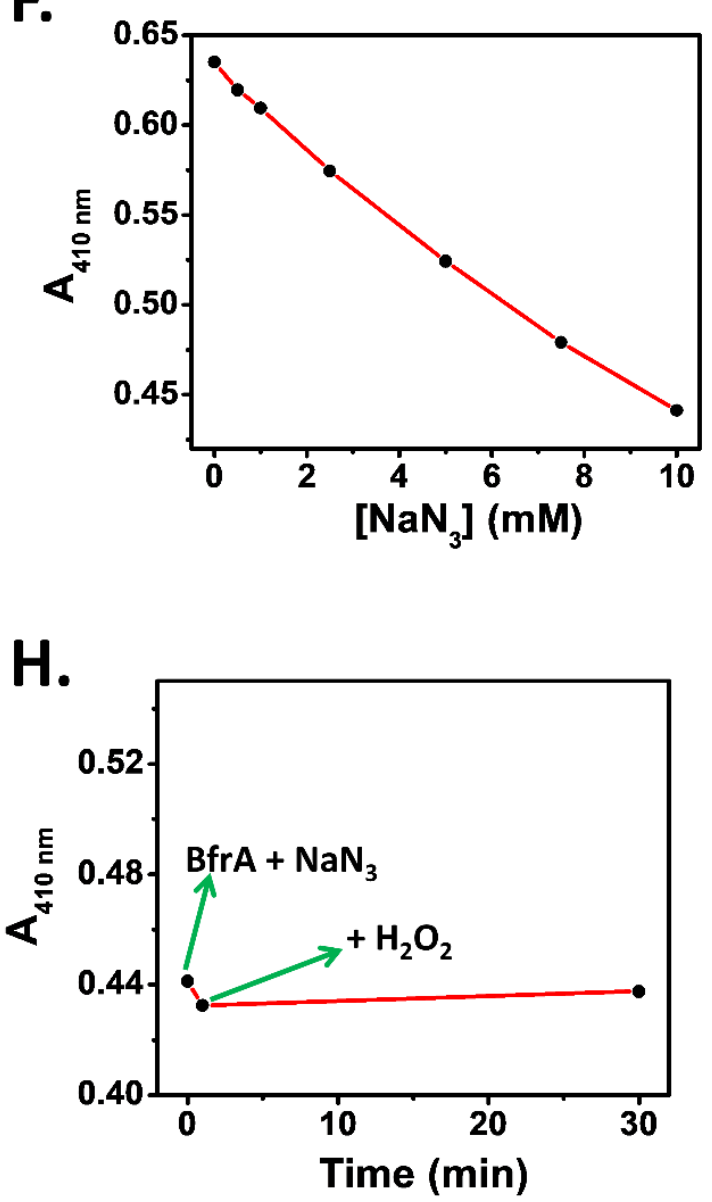

Figure S6: Spectral changes in Soret peak of $M t b$ BfrA during its catalase-like activity and in presence of catalase inhibitors. UV-visible absorption spectra (Scanning kinetics) of $M t b$ BfrA (4.16 $\mu \mathrm{M}$ cage) mixed with (A) $\mathrm{H}_{2} \mathrm{O}_{2}(5 \mathrm{mM}),(\mathbf{C}) \mathrm{NaCN}(0-10 \mathrm{mM})$ and (E) $\mathrm{NaN}_{3}$ (0-10 mM). Corresponding time course changes in the Soret peak absorbance $\left(\mathrm{A}_{410 \mathrm{~nm}}\right)$ after the addition of $(\mathbf{B}) \mathrm{H}_{2} \mathrm{O}_{2}$, (D) $\mathrm{NaCN}(0-10 \mathrm{mM})$ and $(\mathbf{F}) \mathrm{NaN}_{3}(0-10 \mathrm{mM})$ to Mtb BfrA. Mtb BfrA protein only (C-F) was incubated with $\mathrm{CN}^{-} / \mathrm{N}_{3}^{-}$for 5 minutes after each addition followed by recording its spectrum. Changes in the Soret peak absorbance $\left(\mathrm{A}_{410 \mathrm{~nm}}\right)$ are shown, after the addition of $\mathrm{H}_{2} \mathrm{O}_{2}(5 \mathrm{mM})$ to the solution containing (G) Mtb $\mathrm{BfrA}+\mathrm{NaCN}$ and (H) $M t b$ BfrA $+\mathrm{NaN}_{3}$. 


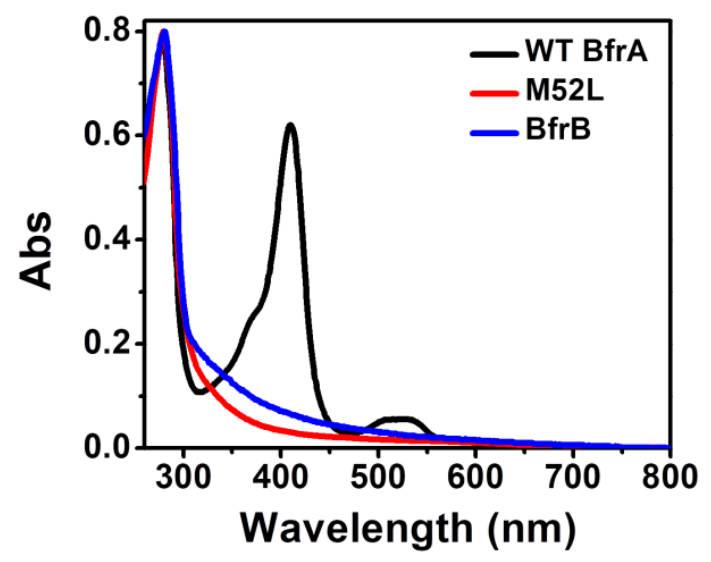

Figure S7: Characterization of heme free BfrA variant, M52L and WT BfrB: UV-visible absorption spectra of M52L BfrA, WT BfrA and WT BfrB protein from Mtb $(\sim 1.0 \mu \mathrm{M}$ protein cage concentration in each case) was recorded in $100 \mathrm{mM}$ MOPS buffer (pH 7.0) using SHIMADZU UV-visible spectrophotometer.
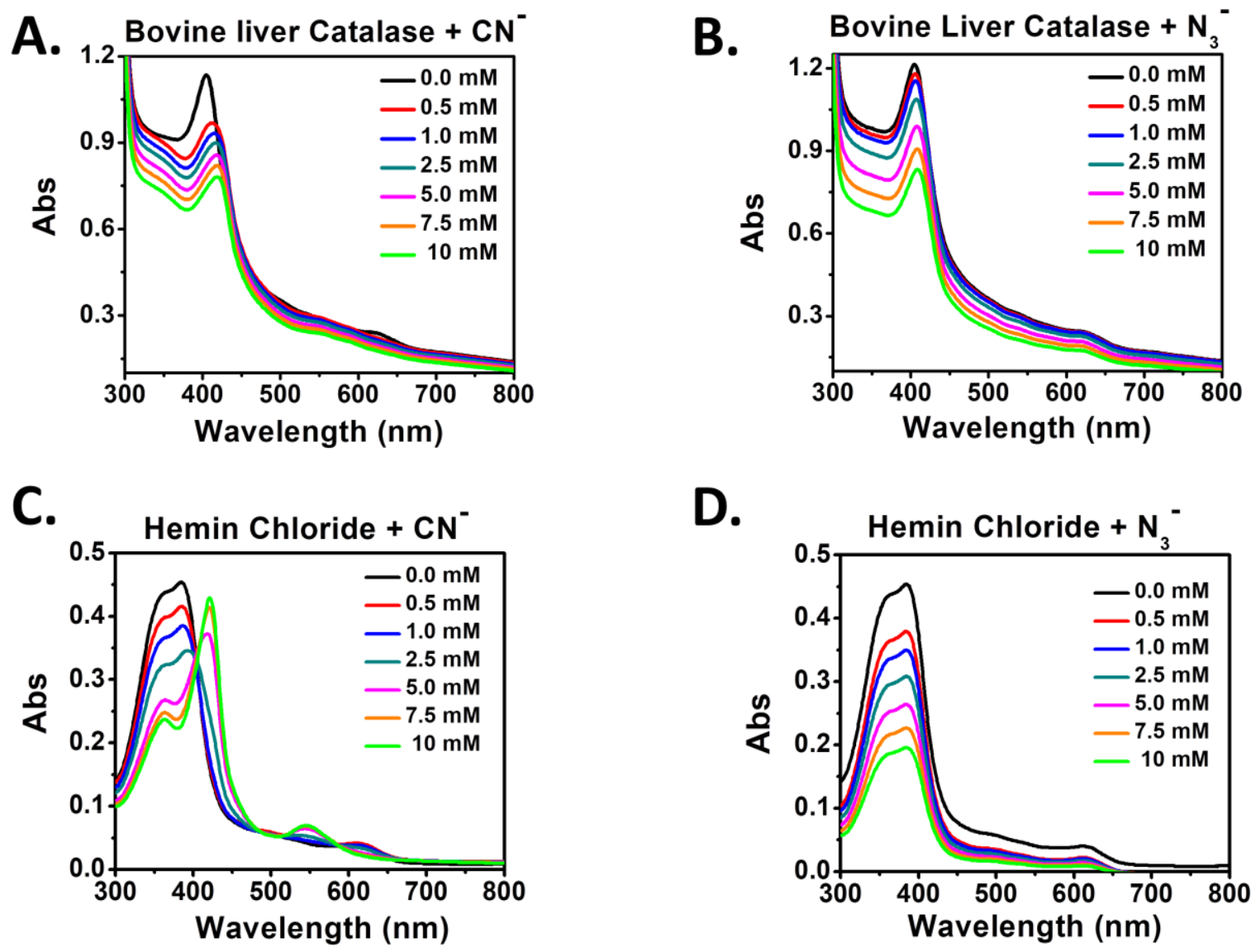

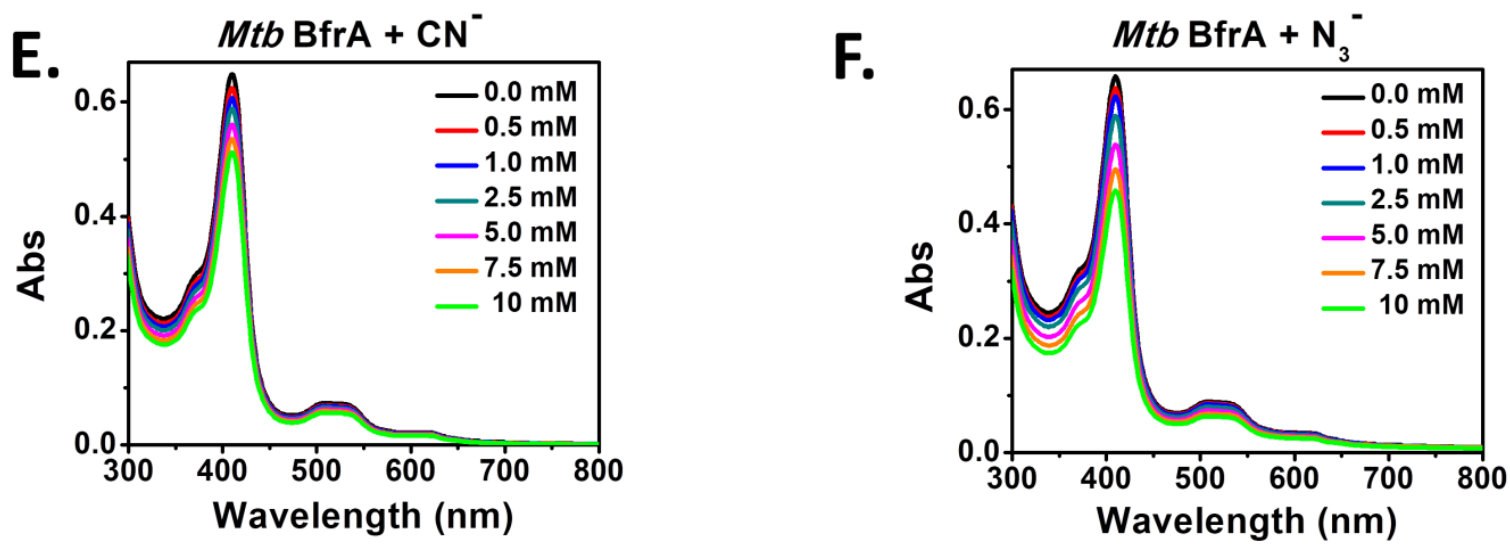

Figure S8: Spectral changes in the Soret peak (position/intensity) of heme proteins in the presence of cyanide and azide. UV-visible absorption spectra of (A-B) bovine liver catalase, (C-D) hemin chloride and (E-F) $M t b$ BfrA protein incubated with $\mathrm{CN}^{-} / \mathrm{N}_{3}{ }^{-}$. The spectrums were recorded after incubating the heme proteins with the increasing concentration $(0-10 \mathrm{mM})$ of $\mathrm{CN}^{-} / \mathrm{N}_{3}{ }^{-}$for 5 minutes each.

A.

B.
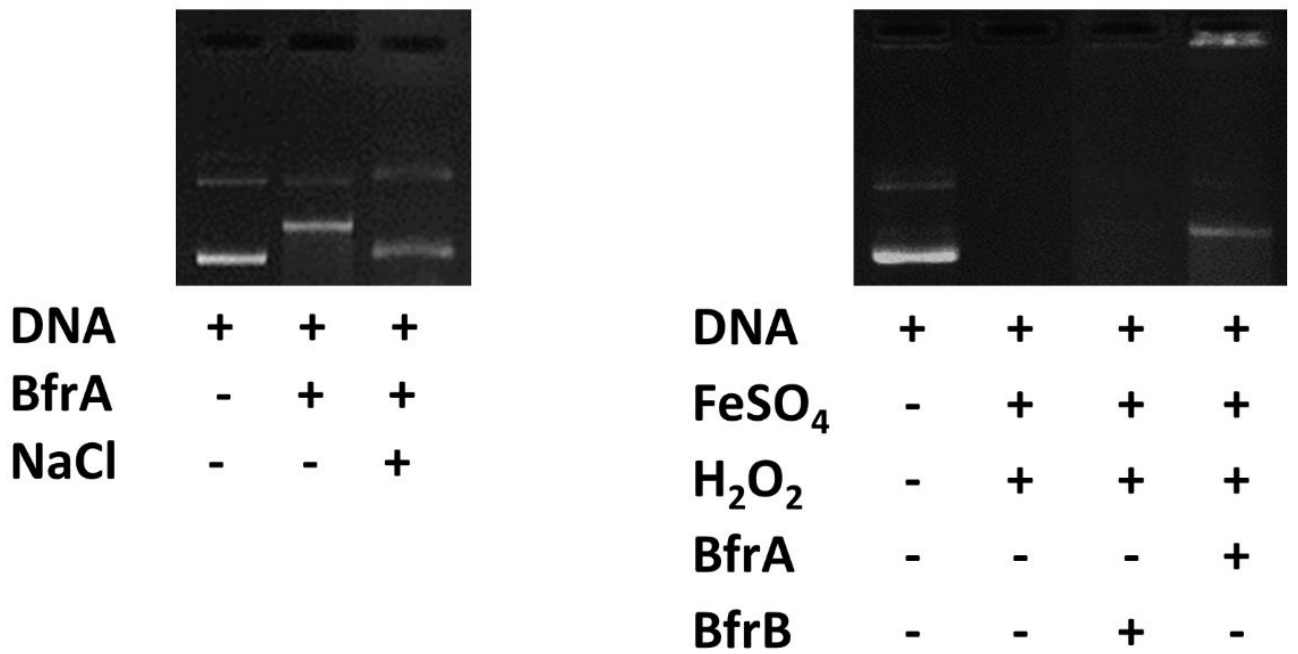

Figure S9: DNA binding studies of $M t b$ Bfr in the presence of salt. (A) DNA-Mtb BfrA interaction in the absence and presence of salt $(\mathrm{NaCl} ; 600 \mathrm{mM})$. (B) Role of $M t b$ BfrA and $M t b$ BfrB during the protection of DNA from Fenton reagents $\left(\mathrm{Fe}^{2+}\right.$ and $\left.\mathrm{H}_{2} \mathrm{O}_{2}\right)$. ' + ' and '-' signs for all lanes indicate the presence and absence of the concerned reactants, respectively. All the above binding and interaction studies were performed using agarose gel $(1 \%, w / v)$ electrophoresis. 

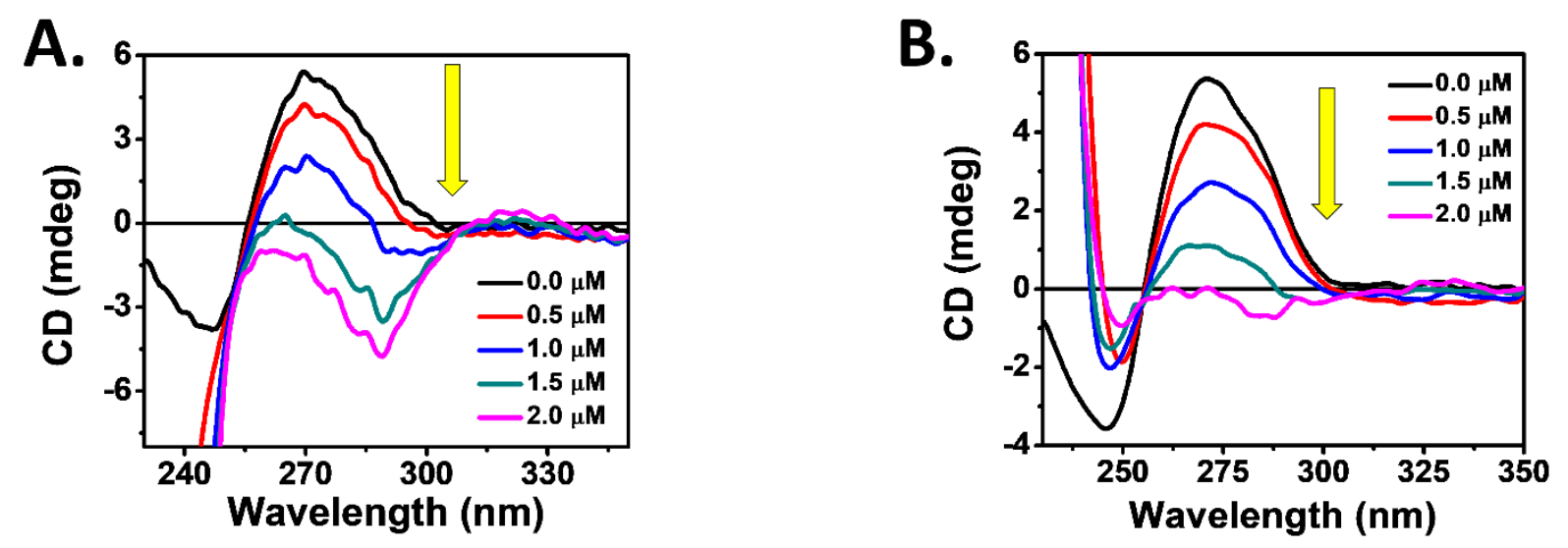

Figure S10: CD spectra of plasmid DNA interaction with Mtb BfrA. (A) CD spectra of plasmid DNA (pBR322, $25 \mu \mathrm{g}$ ) with the addition of increasing concentration of Mtb BfrA (0.5-2.0 $\mu \mathrm{M}$ cage) (B) Corresponding CD spectra after volume correction and removal of signals contributed by $M t b$ BfrA protein alone. CD spectra were collected on a Jasco J-1500 CD Spectrometer in the UV range (230-350 nm) using $2 \mathrm{~mm}$ quartz cuvette at $20^{\circ} \mathrm{C}$. Each of the spectra obtained were the average of five scans.

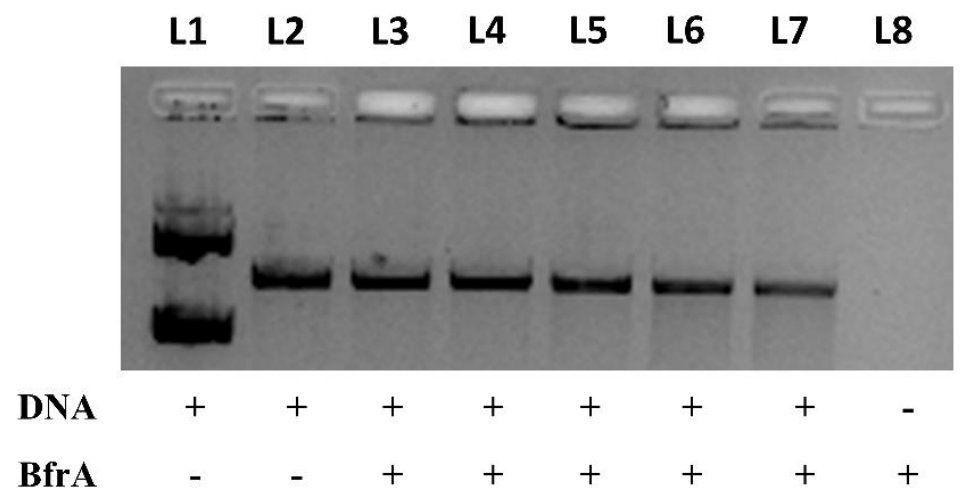

Figure S11: Linear DNA-Mtb BfrA interaction by EMSA. Mtb BfrA protein concentration was varied $(0.5-2.5 \mu \mathrm{M})$, keeping the concentration of pDNA $(8 \mathrm{nM})$ and linear DNA fixed (8 nM). Lanes 3-7 (L3-L7) represent Mtb BfrA protein (0.5, 1.0, 1.5, 2.0 and $2.5 \mu \mathrm{M})$ incubated with linear DNA $(8 \mathrm{nM})$ in each lane. Only plasmid DNA $(8 \mathrm{nM})$ and linear DNA $(8 \mathrm{nM})$ are indicated at the extreme left, L1 and L2 respectively with only Mtb BfrA protein in L8 of the agarose gel. '+' and '-' signs for all lanes indicate the presence and absence of the concerned reactants, respectively. 


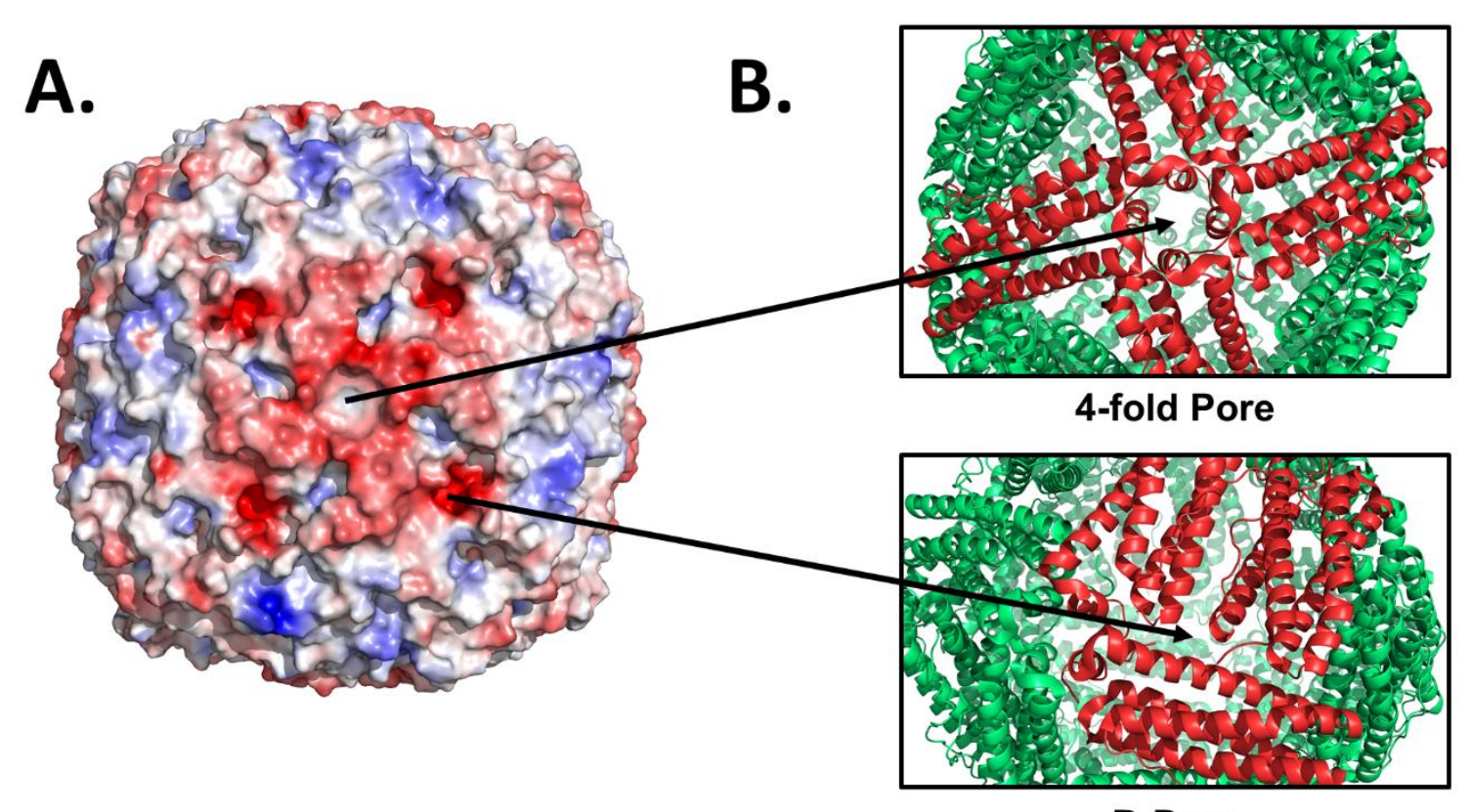

B-Pore

Figure S12: Surface electrostatics of Mtb BfrA. (A) Vacuum electrostatics of $M t b$ BfrA generated from PDB ID: 3UOI using PyMOL. Red and Blue patches on Mtb BfrA surface indicates the presence of negatively and positively charged amino acid residues with the presence of highly negatively charged region at the B-pores as well as surrounding the 4-fold pores, as shown in enlarged view in (B). 


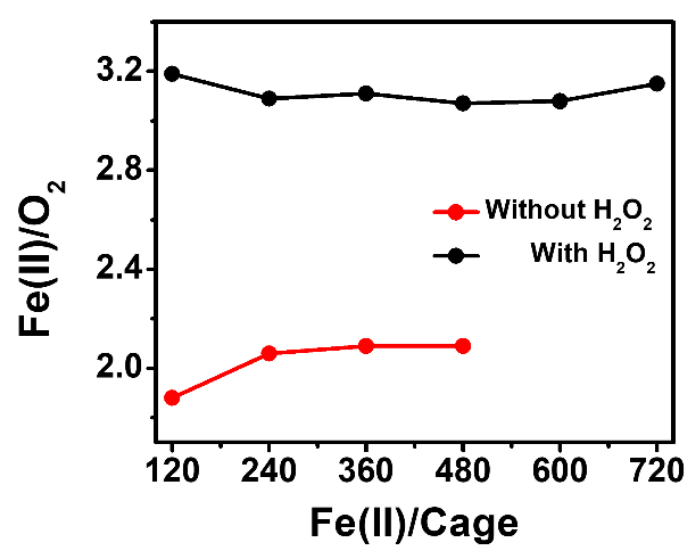

Figure S13: $\mathbf{F e}\left(\right.$ II): $\mathbf{O}_{2}$ stoichiometry vs. Fe(II)/Cage for $120 \mathrm{Fe}(\mathrm{II})$ atoms/cage per injection in the presence (black circles) and absence (red circles) of $\mathrm{H}_{2} \mathrm{O}_{2}$. Conditions: $1.0 \mu \mathrm{M} M t b$ BfrA nanocage with the injection of $120 \mu \mathrm{M} \mathrm{FeSO}_{4}$ with $(60 \mu \mathrm{M})$ and without $(0 \mu \mathrm{M}) \mathrm{H}_{2} \mathrm{O}_{2}$ each addition in $100 \mathrm{mM}$ MOPS (pH 7.0) at $25.0{ }^{\circ} \mathrm{C}$. Refer to Fig.3.D in the main manuscript.
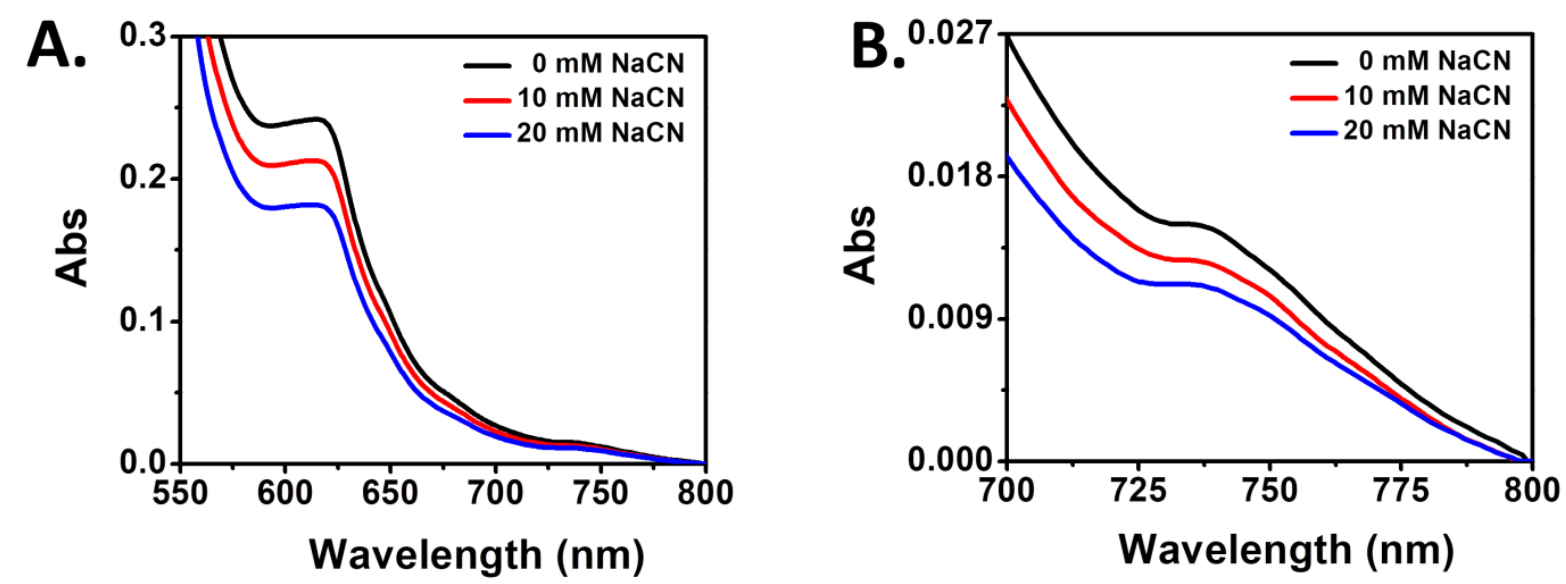

Figure S14: Spectral changes in the methionine-heme coordination band of Mtb BfrA upon incubation with cyanide. Solution of Mtb BfrA protein in $100 \mathrm{mM}$ MOPS (pH 7.0) was concentrated using $30 \mathrm{kDa}$ MWCO membrane for 20 min under $4500 \mathrm{rpm}$ at $4^{\circ} \mathrm{C}$. It was then incubated with increasing concentration $(0-20 \mathrm{mM})$ of $\mathrm{CN}^{-}$for 20 min each. The UVvisible absorption spectra were recorded using SYNERGY H1 multimode microplate reader and are shown for the wavelength region (A) 550-800 $\mathrm{nm}$ and (B) 700-800 nm. 